\title{
DEVELOPMENT OF NANO MULLITE BASED MESOPOROUS SILICA BIOCER WITH INCORPORATED BACTERIA FOR ARSENIC REMEDIATION
}

\author{
SUBRATA KAR*, PAPIYA NANDY**, RUMA BASU**,***, " ${ }^{*}$ SUKHEN DAS*,**,**** \\ *Physics Department, Jadavpur University, Kolkata-700 032, India. \\ **Centre for Interdisciplinary Research and Education, Kolkata 700 068, India \\ ***Physics Department, Jogamaya Devi College, Kolkata 700 026, India \\ ****Indian Institute of Engineering, Science and Technology, Howrah, India \\ "E-mail: sdasphysics@gmail.com
}

Submitted October 27, 2015; accepted May 10, 2016

\begin{abstract}
Keywords: Biocer, Mullite, Silica, Arsenic bacteria, Entrapment, Viability
Nanomullite based silica matrix was employed to entrap an arsenic(As(V)) degrading bacteria using sol-gel process. The bacteria were cultured in arsenic environment in their sub-MIC concentration to acclimatize and direct them to utilize arsenic. The matrix with and without microorganisms were characterized by FESEM and BET surface area. The bacteria remained $75 \%$ viable within the matrix as monitored up to 120 days. The enzymatic activity was also observed by fluorescein diacetate assay. The mullite assisted silica biocer provides a good material for bacteria entrapment preserving its metabolic activity therefore may be utilized as a possible candidate for arsenic remediation matrix.
\end{abstract}

\section{INTRODUCTION}

Immobilization of biocomponent within the inorganic matrix is a matter of considerable interest as a successful technical answer for long term bioefficiency [1]. Biomolecules immobilization by sol-gel process using porous inorganic materials provides several advantages over polymeric matrices in terms of their water retaining ability, room temperature preparation, chemical durability, mechanical strength etc. [2, 3]. Previous works for encapsulation of biocomponent within inorganic matrices utilized zirconium oxyhydroxide, silica gels, porous silicon etc. as substrate [4, 5]. An ideal bio matrix for its wide range of applications should possess the following characteristics such as high mechanical strength, inertness, biocompatibility and non-toxicity vs. active biological agents [6].

Bioceramics (biocers) are nanosized ceramic material to encapsulate biological cells that may be bacterial, fungi, plant, animal cells or biologically derived proteins and enzymes (7). Mullite $\left(3 \mathrm{Al}_{2} \mathrm{O}_{3} \cdot 2 \mathrm{SiO}_{2}\right)$ is the mineralogical name of only chemically stable intermediate phase in the $\mathrm{SiO}_{2}-\mathrm{Al}_{2} \mathrm{O}_{3}$ system possessing high mechanical strength, chemical inertness and low thermal expansion co-efficient. The use of mullite as a reinforcing agent in the synthesis of hydroxyapatite based bone replacement biomaterials and biocers suggests its role as biocompatible material [8]. Therefore nano-mullite ceramic matrix can be a good candidate pertaining to its nontoxic nature, moderate surface area and high mechanical strength.
Arsenic poisoning in ground water is a matter of serious concern all over the world specially in countries like Bangladesh, Chile, India, Nepal, Thailand, and Vietnam, where arsenic occurs naturally in groundwater at concentrations exceeding the guidelines of the World Health Organization $\left(10 \mu \mathrm{g} \cdot \mathrm{l}^{-1}\right)$, causing serious health problems and human mortality. Amongst various treatment options, for the removal of arsenic from contaminated water, the surface modified adsorbents and biological treatment with living microbes are gaining momentum in recent years [9]. Microbes employ a wide range of strategy for arsenic resistance and remediation [10]. Arsenate reductases from bacteria are heterodimeric proteins either located at the periplasm or are membrane associated [11]. Although all the arsenic bacteria can survive in arsenic atmosphere, the bacteria type which reduces $\mathrm{As}(\mathrm{V})$ to $\mathrm{As}(\mathrm{III})$ and accumulate $\mathrm{As}(\mathrm{III})$ is specifically termed as arsenic resistant bacteria. Arsenic resistant bacteria normally contain arsR and arsC gene in either plasmid or chromosome or in both and produce arsenic regulatory ArsR protein and arsenate reductase enzyme. ArsR has specific active sites for accumulating As(III). This arsR-arsC gene cluster has been observed in Ralstonia eutropha $\mathrm{CH} 34$ which is also known as $R$. eutropha MTCC 2487 which was isolated from $\mathrm{Zn}$ factory wastewater. Arsenic removal efficiency of bacteria improves when it is immobilized on a solid support [11].

In our present work, Ralstonia eutropha (MTCC 2487) was grown with increasing concentration of arsenate in nutrient broth and the minimum inhibitory 
concentration (MIC) was obtained. Arsenate at sub MIC concentration was used to culture the bacteria with gradual decreasing concentration of nutrient broth to gradually direct bacteria to grow and utilize $\mathrm{As}(\mathrm{V})$ and convert into As(III) as confirmed by arsenic reductase enzyme assay. Nanomullite based silica matrix was used to entrap the $\mathrm{As}(\mathrm{V})$ consuming bacteria by sol-gel process. The matrix was characterized by SEM, BET surface area. The viability of the biocer was also studied using plate count method and Fluorescein diacetate (FDA) staining with respect to time. Results indicates a successful encapsulation of the arsenic reducing bacteria within the mullite assisted silica matrix, therefore finding its application as a biocer for removal of arsenic.

\section{EXPERIMENTAL}

Materials

Ludox AS colloidal silica (Sigma Aldrich), Aluminium isopropoxide (Loba Chemie), TEOS, Ethanol (Merck Germany), Beef extract, Peptone, Yeast extract, Agar (Himedia Pvt. Ltd., India), Ralstonia eutropha MTCC 2487 (IMTECH Chandigarh, India). Analytical grade sodium arsenate $\left(\mathrm{Na}_{2} \mathrm{HAsO}_{4} \cdot 7 \quad \mathrm{H}_{2} \mathrm{O}\right)$ (s.d.fine chemicals, India) were used to prepare stock solutions of As(V).

\section{Methods}

\section{Synthesis of nanoporous mullite}

Mullite was synthesized by sol-gel process using aluminium isopropoxide and tetra ethyl ortho silicate (TEOS) as reported by Kar et al. 2014 [12]. Briefly, $15.32 \mathrm{~g}$ of aluminium isopropoxide was dispersed in ethanol (99.99\% pure) and mixed by stirring in a magnetic stirrer. This was followed by addition of $5.21 \mathrm{~g}$ of TEOS with a micropipette and the stirring is continued for $24 \mathrm{~h}$ at $35^{\circ} \mathrm{C}$. The solution was then stirred for $2 \mathrm{~h}$ at $60^{\circ} \mathrm{C}$ and thereafter hydrolyzed by adding $20 \mathrm{ml}$ of distilled water. The gel thus obtained was dried at $70^{\circ} \mathrm{C}$ in the oven. The mullite precursor thus formed was powdered by crushing and was sintered at $1300^{\circ} \mathrm{C}$ in the furnace for $4 \mathrm{~h}$.

\section{Preparation of Biocer \\ Preparation of bacteria}

Bacteria were cultured and subcultured in LB medium for sufficient growth. After $48 \mathrm{hr}$ of incubation, bacteria were washed by centrifugation at $6000 \mathrm{~g}$ for 10 mins and washed with PBS buffer $\mathrm{pH}$ 7.4.

\section{Determination of MIC}

Bacteria at concentration $\sim 10^{6}$ were inoculated in LB medium(13 $\left.\mathrm{g} \cdot \mathrm{l}^{-1}\right)$ supplemented with sodium arsenate solution at concentration of $2 \mathrm{mg} \cdot 1^{-1}$ to $200 \mathrm{mg} \cdot \mathrm{l}^{-1}$.
Minimum inhibitory concentration of sodium arsenate was defined by the concentration at which there is no visible growth.

\section{Growth kinetics}

Bacteria were inoculated $\sim 10^{6} \mathrm{CFU} \mathrm{ml}^{-1}$ of bacteria in LB medium in presence of 10,50 and $100 \mathrm{mg} \cdot \mathrm{l}^{-1}$ of arsenate and incubated at $30^{\circ} \mathrm{C}$. Growth was monitored at $0,4,8,12,18,24,30,40,50$ and $60 \mathrm{hr}$ by measuring the optical density at $600 \mathrm{~nm}$. The experiment was repeated thrice to reproduce the data.

\section{Acclimatization of bacteria}

Bacteria were acclimatized and directed to grow in arsenic environment by gradual decrease of nutrient broth concentration from $13 \mathrm{~g} \cdot \mathrm{l}^{-1}$ to $2 \mathrm{~g} \cdot \mathrm{l}^{-1}$ in presence of $80 \mathrm{mg} \cdot \mathrm{l}^{-1}$ (sub-MIC concentration) of arsenic for a period of 2 months.

\section{Arsenic Reductase assay}

To confirm the ability of the induced bacteria to reduce arsenate $(\mathrm{As}(\mathrm{V}))$ was determined by arsenic reductase assay according to Anderson and Cook, 2003 [13]. The assay was performed as follows:

Acclimatized bacteria was grown for $48 \mathrm{hr}$ in nutrient broth $\left(2 \mathrm{~g} \cdot \mathrm{l}^{-1}\right)$ and $80 \mathrm{mg} \cdot \cdot^{-1}$ of $\mathrm{As}(\mathrm{V})$ at $30^{\circ} \mathrm{C}$. Bacteria was harvested by centrifugation at $7500 \mathrm{~g}$ for 10 mins and washed three times and finally suspended

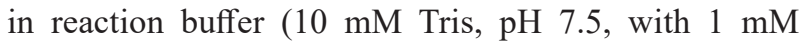
$\mathrm{Na}_{2}$ EDTA and $1 \mathrm{mM} \mathrm{MgCl}_{2}$ ). Cells were broken by sonication in ice cold condition. Unbroken cells were separated by centrifugation at $7500 \mathrm{~g}$ for $10 \mathrm{mins}$ at $4^{\circ} \mathrm{C}$. The supernatant was used for arsenate reductase assay. The assay was based on NADPH oxidation, which is coupled to the enzyme ArsC reductase activity. NADPH oxidation was initiated at $37^{\circ} \mathrm{C}$ by mixing $50 \mu \mathrm{l}$ of crude extract in $820 \mu \mathrm{l}$ of reaction buffer, $30 \mu \mathrm{l}$ of $10 \mathrm{mM}$ DTT, $50 \mu \mathrm{l}$ of $2 \mathrm{mM}$ arsenate (final concentration $100 \mu \mathrm{M}$ ), and $50 \mu \mathrm{l}$ of $3 \mathrm{mM}$ NADPH. Arsenate concentrations of $500 \mu \mathrm{M}$ and $1 \mathrm{mM}$ were assayed along with the same concentrations of arsenite and 'no arsenic' for controls. The samples were incubated at $37^{\circ} \mathrm{C}$ after which absorbance was recorded at $340 \mathrm{~nm}$, where $0.15 \mathrm{mM}$ NADPH has an absorbance of approximately 1.0. Absorbance decreases as NADPH is oxidized coupled to arsenate reduction to arsenite [13].

\section{Immobilization of Bacteria}

Colloidal silica $2 \mathrm{ml}$ was mixed with $0.5 \mathrm{ml} \mathrm{Na}$ silicate ( 1 gm sodium silicate in $6 \mathrm{ml}$ ) was slowly added and mixed thoroughly in magnetic stirrer. Mullite was added to the mixture and thoroughly stirred for $30 \mathrm{mins}$. The gelation of the mullite reinforced colloidal silica was initiated by addition of $0.1 \mathrm{M} \mathrm{HCl}$ drop by drop, with constant monitoring of $\mathrm{pH}$. At approximately $\mathrm{pH} \sim 8$ bacterial culture was added at concentration of $10^{8} \mathrm{CFU} \mathrm{ml}^{-1}$. Appropriate amount of glycerol was added 
as cryoprotectant. Finally $\mathrm{pH}$ was further lowered to $\sim 7$, geletion was induced in a few minutes. The biocer was then stored at $-20^{\circ} \mathrm{C}$ for $24 \mathrm{~h}$ and then freeze dried in a lyophilliser. The same process was followed without the bacteria. The schematic process of the preparation of biocer is shown in Figure 1.

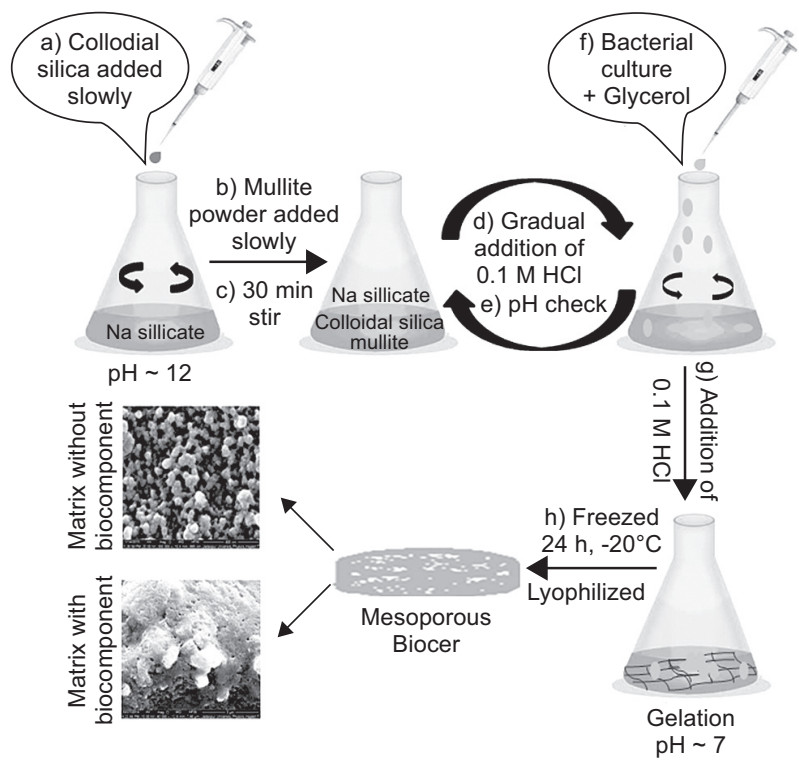

Figure 1. Preparation of biocer using sol-gel process.

\section{Cell Number}

Biocer (10 mg) was added to a 1-ml PBS (pH 7.4) and ground carefully with a pestle. To determine the cell number (Colony Forming Units, CFU) the suspension was plated on nutrient broth for $0,4,15,30,45,60,80$, 100,120 days.

\section{Activity}

Fluorescein diacetate (FDA) is hydrolysed by a number of different enzymes, such as esterases, proteases and lipases to fluorescein. FDA (Sigma-Aldrich Chemie, Steinheim, Germany) was dissolved in acetone and stored as a stock solution $\left(2 \mathrm{mg} \cdot \mathrm{ml}^{-1}\right)$ at $20^{\circ} \mathrm{C}$. Biocer (10 mg) was added to a tube containing $4 \mathrm{ml}$ nutrient broth, $4 \mathrm{ml}$ water, $32 \mu \mathrm{FDA}$ and shaken at $30^{\circ} \mathrm{C}$ for 20 - 30 mins followed by washing 3 times in distilled water [14]. A drop of it was casted on a glass slide and dried in vacuum. Slide was then observed under fluorescence microscope under in blue filter (Axio Scope. A1, Zeiss)

\section{BET surface area}

The specific surface area of the powders was measured using the Brunauer- Emmett-Teller (BET) surface area analyzer (Autosorb 1, Quantachrome Corporation, Syosset, NY) at liquid nitrogen temperature (77 K). The pore size distribution was evaluated with the Barrer-Joyner-Halenda (BJH) method.

\section{Scanning Electron Microscopy}

Morphological characteristics of the biocer both with and without biocomponent were observed by scanning electron microscope (SEM) model FEI Quanta 250 (USA). A minute quantity of the sample was directly placed on carbon coated grid, sputter coated with gold and then observed by SEM.

\section{RESULTS AND DISCUSSION}

Growth kinetics of the bacteria in presence of $\mathrm{As}(\mathrm{V})$ at different concentration is shown in Figure 2.

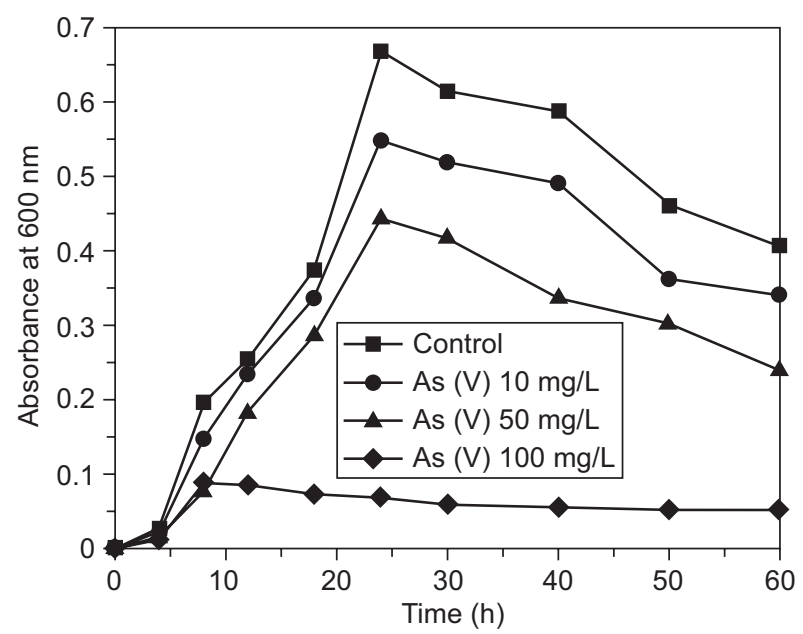

Figure 2. Effect of arsenic concentration on the growth of R. eutropa.

As seen in the Figure 2 presence of arsenic (V) delays the growth of bacteria with respect to the control for $10-50 \mathrm{mg} \cdot \mathrm{l}^{-1}$. Growth was totally inhibited in presence of $100 \mathrm{mg} \cdot l^{-1}$ of arsenate where bacterial growth stopped after $8 \mathrm{hr}$ reaching the stationary phase.

The Arsenic reductase assay with bacterial protein reveals its ability to reduce As(V) into As(III). As substrate concentration form $0.1 \mathrm{mM}$ to $0.5 \mathrm{mM}, 1 \mathrm{mM}$ the percentage of reduction was 38.02, 44.06 and $51.10 \%$ respectively. The result confirms that the bacteria were not only acclimatized to grow in arsenic environment, they also adapted to utilize arsenic.

As seen in the Figure 3 the viability of the immobilized bacteria slightly decreases with time. After 120 days of immobilization the viability of the bacteria was $\sim 75 \%$ to that of the initial cell concentration.

Fluorescence microscopic image of the Bacteria entrapped in the mullite based biocer shows good enzymatic activity at 120 days of post immobilisation suggeesting the good metabolic activity of the bacterial cells within the biocer (Figure 4).

The specific surface area, pore volume and pore diameter of the biocer with bacterial entrappped is shown in Table 1. The data shows that all the parameters incerased after the bacterial immobilisation. This is due 
to the fact that the size of the entrapped bacteria is far bigger than the pores and addition of which during the pore formtion effectively act as a template around which the porous network is formed [15]

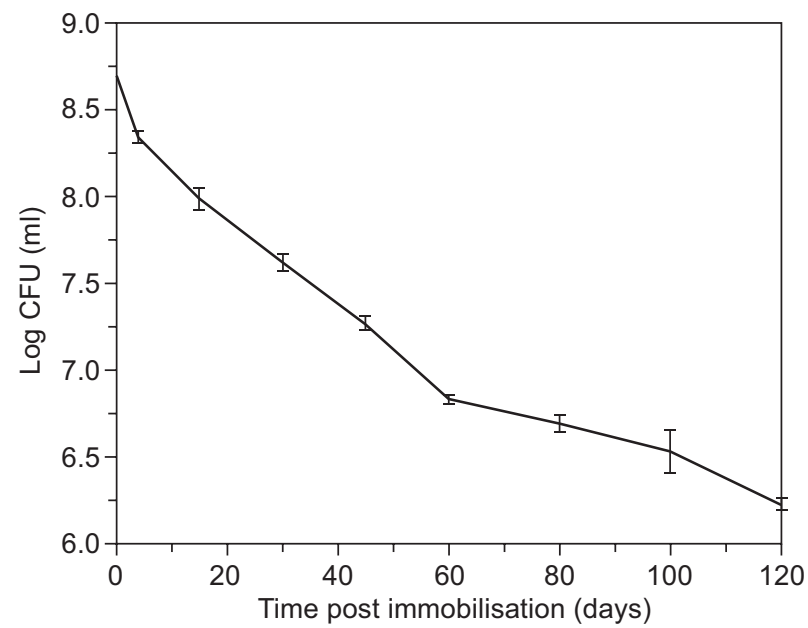

Figure 3. Viability of biocomponent within the biocer.
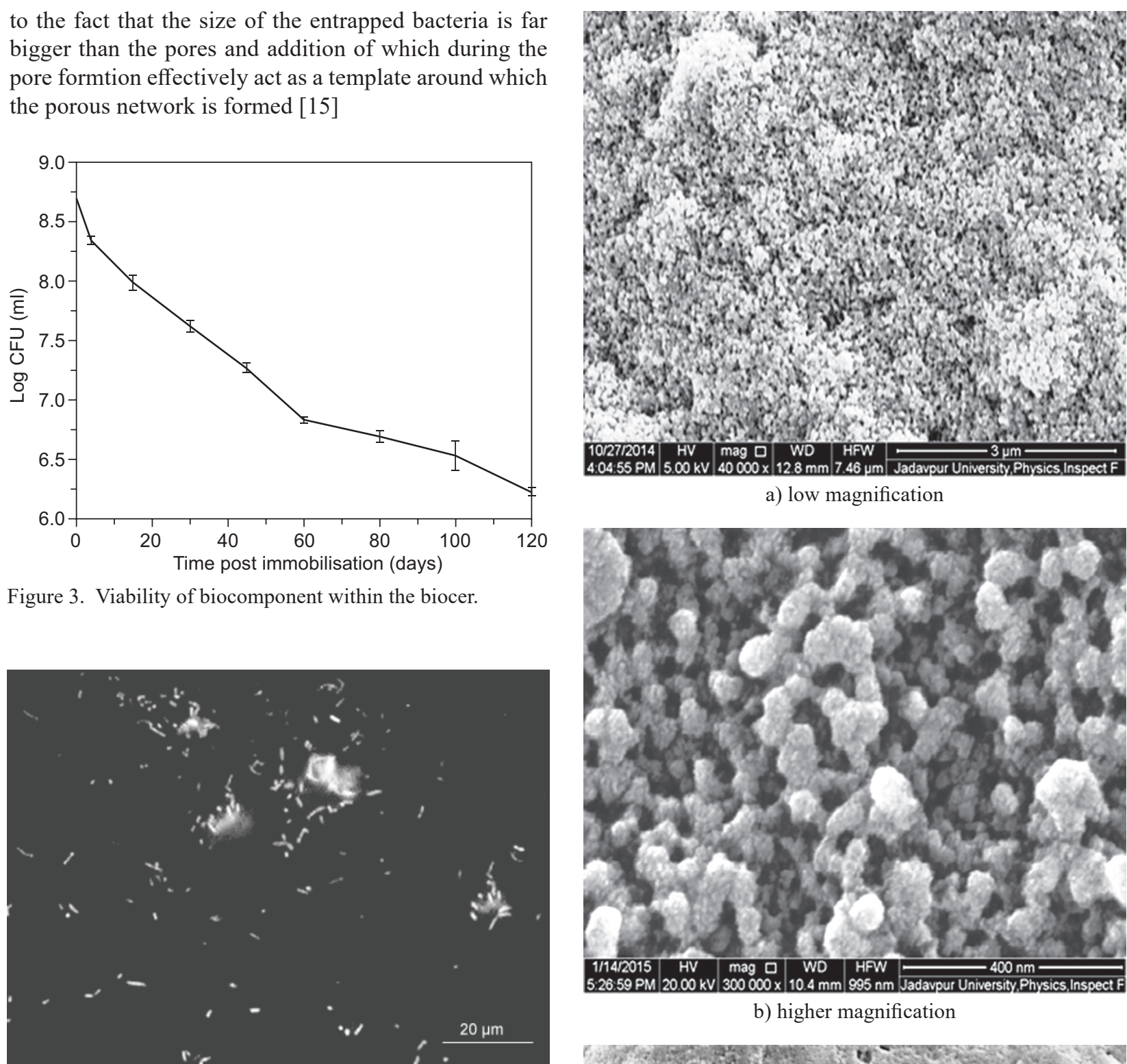

a) low magnification

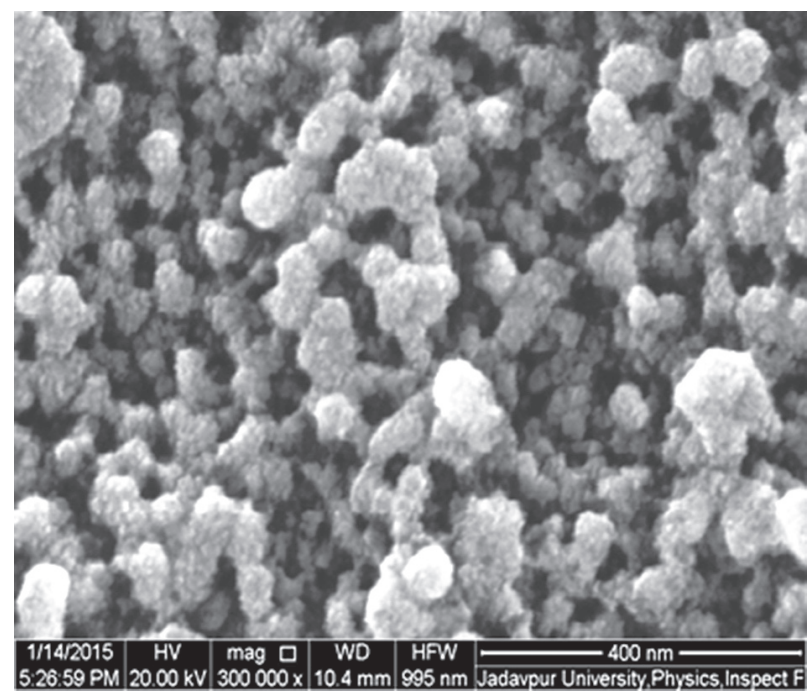

b) higher magnification

a) 4 days

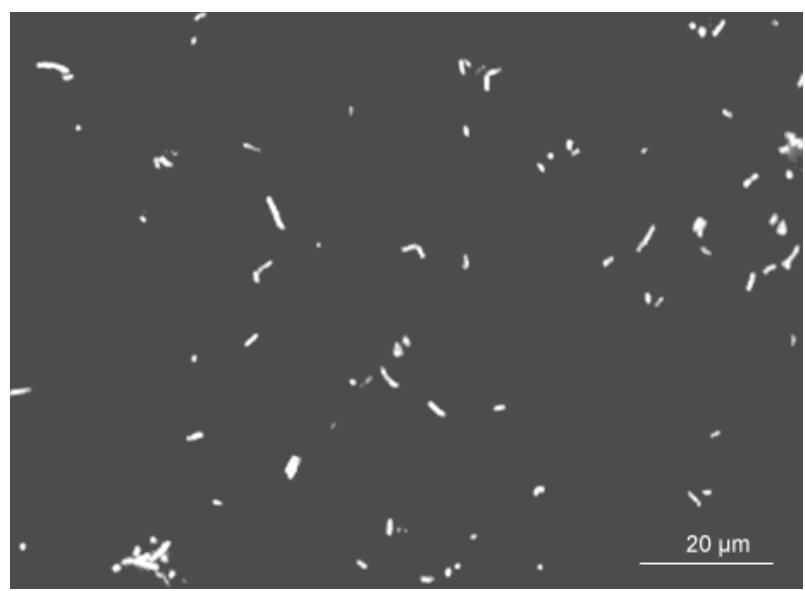

b) 120 days

Figure 4. Fluorescence microscopic image of $R$. eutropa immobilised in Biocer after 4 days a) and 120 days b) of post immobilisation.

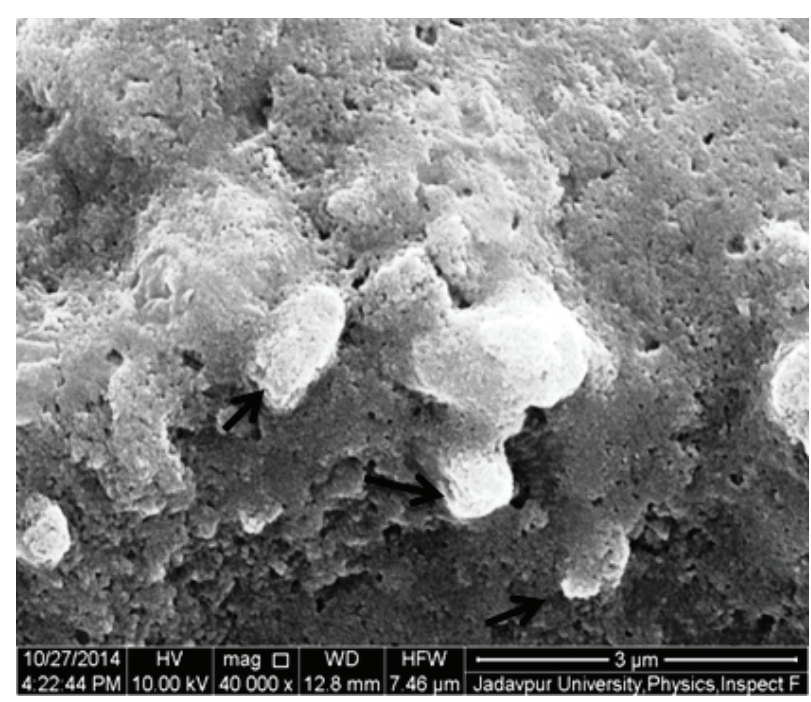

c) with bacteria

Figure 5. SEM image of the Biocer without bacteria: a) at low magnification, b) at higher magnification and c) Biocer with bacteria. 
Table 1. BET surface area, average pore volume and pore volume of biocer without and with biocomponent (bacteria).

\begin{tabular}{lcc}
\hline Biocer & Without cells & With cells \\
\hline BET surface area $\left(\mathrm{m}^{2} \cdot \mathrm{g}^{-1}\right)$ & 36.933 & 69.52 \\
BET average pore diameter $(\mathrm{nm})$ & 3.720 & 8.4 \\
BJH desorption pore volume $\left(\mathrm{cc} \cdot \mathrm{g}^{-1}\right)$ & 0.073 & 0.16 \\
\hline
\end{tabular}

The surface of the matrix is shown in figure 5a,b displaying its mesoporous nature. The surface of the biocer containing bacteria is shown in the Figure 5c. Only impressions of the bacteria is seen visible due to the technical limit of the SEM which is surface specific and does not probe the bulk of the sample.

\section{CONCLUSION}

The sol-gel process of entrapping bacteria using mesoporous silica matrix reinforced with nano mullite proves to be a good technique to preserve long term viability and enzyme activity of the biocomponent. The biocomponent used in this work is an arsenic degrading bacteria, which was first acclimatized to utilize arsenic followed by its immobilization within biocer. The contaminant $\mathrm{As}(\mathrm{V})$ has been converted to $\mathrm{As}(\mathrm{III})$ and subsequently entrapped by the Bacteria and as a result of which the water has been purified. Therefore the matrix can be a potential good candidate for the developing filter for arsenic removal which is a matter of great concern in several parts of the world.

\section{REFERENCES}

1. Callone E., Campostrini R., Carturan G., Cavazza A., Guzzon R. (2008): Immobilization of yeast and bacteria cells in alginate microbeads coated with silica membranes: procedures, physico-chemical features and bioactivity. Journal of materials chemistry, 18(40), 4839-4848. doi:10.1039/B807301E

2. Nassif N., Bouvet O., Rager M.N., Roux C., Coradin T., Livage J. (2002): Living bacteria in silica gels. Nature materials, 1(1), 42-44. doi:10.1038/nmat709

3. Kandimalla V.B., Tripathi V.S.,Ju,H.(2006): Immobilization of biomolecules in sol-gels: biological and analytical applications. Critical Reviews in Analytical Chemistry, 36(2), 73-106. doi:10.1080/10408340600713652

4. Perullini M., Amoura M., Jobbágy M., Roux C., Livage J., Coradin T., Bilmes S.A. (2011): Improving bacteria viability in metal oxide hosts via an alginate-based hybrid approach. Journal of Materials Chemistry, 21(22), 80268031. doi:10.1039/C1JM10684H

5. Borkowski A., Szala M., Cłapa, T. (2015): Adsorption Studies of the Gram-Negative Bacteria onto Nanostructured Silicon Carbide. Applied biochemistry and biotechnology, 175(3), 1448-1459. doi:10.1007/s12010-014-1374-4

6. Coiffier, A., Coradin, T., Roux, C., Bouvet, O. M., \& Livage, J. (2001). Sol-gel encapsulation of bacteria: a comparison between alkoxide and aqueous routes. Journal of Materials Chemistry, 11(8), 2039-2044. doi:10.1039/ B101308O

7. Böttcher H., Soltmann U., Mertig M., Pompe W. (2004): Biocers: ceramics with incorporated microorganisms for biocatalytic, biosorptive and functional materials development. Journal of Materials Chemistry, 14(14), 2176-2188. doi:10.1039/B401724B

8. Nath S., Biswas K., Wang K., Bordia R. K., Basu B. (2010): Sintering, Phase Stability, and Properties of Calcium Phosphate-Mullite Composites. Journal of the American Ceramic Society, 93(6), 1639-1649. doi:10.1111/j.15512916.2010.03662.x

9. Kim H.C., Lee C.G., Park J.A., Kim S.B. (2010): Arsenic removal from water using iron-impregnated granular activated carbon in the presence of bacteria. Journal of Environmental Science and Health Part A, 45(2), 177-182. doi:10.1080/10934520903429832

10. Mateos L.M., Ordóñez E., Letek M., Gil J. A. (2006): , Corynebacterium glutamicum" as a model bacterium for the bioremediation of arsenic. International microbiology: official journal of the Spanish Society for Microbiology, 9(3), 207-216.

11. Mondal P., Majumder C.B., Mohanty, B. (2008): Treatment of arsenic contaminated water in a batch reactor by using Ralstonia eutropha MTCC 2487 and granular activated carbon. Journal of hazardous materials, 153(1), 588-599. doi:10.1016/j.jhazmat.2007.09.028

12.Kar S., Bagchi B., Kundu B., Bhandary S., Basu R., Nandy P., Das, S. (2014): Synthesis and characterization of $\mathrm{Cu} / \mathrm{Ag}$ nanoparticle loaded mullite nanocomposite system:Apotential candidate for antimicrobial and therapeutic applications. Biochimica et Biophysica Acta (BBA)-General Subjects, 1840(11), 3264-3276. doi:10.1016/j.bbagen.2014.05.012

13. Anderson C.R., Cook, G.M. (2004): Isolation and characterization of arsenate-reducing bacteria from arsenic-contaminated sites in New Zealand. Current microbiology, 48(5), 341-347. doi:10.1007/s00284-003-4205-3

14. Soltmann U., Böttcher H., Koch D., Grathwohl G. (2003): Freeze gelation: a new option for the production of biological ceramic composites (biocers). Materials Letters, 57(19), 2861-2865. doi:10.1016/S0167-577X(02)01388-5

15.Rooke J.C., Léonard A., Su B.L. (2008): Targeting photobioreactors: Immobilisation of cyanobacteria within porous silica gel using biocompatible methods. Journal of Materials Chemistry, 18(12), 1333-1341. doi:10.1039/ B717990A 